\title{
THE DEVELOPMENT OF CHILD SEX EXPLOITATION COMMERCIAL (CSEC) "RESPONSE MODEL IN MEDAN CITY"
}

\author{
Ahmad Fauzi ${ }^{1 *}$, T.Riza Zarzani ${ }^{1}$ \\ ${ }^{1}$ University of Muhammadiyah Sumatera Utara, Medan, Indonesia \\ *Corresponding Author: dr.ahmadfauzi.af@gmail.com
}

\begin{abstract}
The Child of Sex Exploitation Commercial (CSEC) is a fundamental violation of the rights of children. The violation is sexual violence by an adult with a gift to a child, or a third person, or other persons. Simply put, children are treated as sexual and commercial objects. This is a manifestation of forced labor and modern slavery, because not a few children are forced and subjected to physical violence and trauma. The purpose of this study is to examine the legal arrangements for the sexual exploitation of children in Indonesia, to examine and analyze prevention and mitigation of CSEC in Medan City, and to examine barriers to prevention and overcoming of CSEC and how to overcome it. This study uses sociological juridical approach that comes from primary data and secondary data. Data were collected through document studies and interviews conducted to Medan City Center for Childhood Study and Protection (PKPA) staff. The results of the study indicate that the legal arrangement of CSEC in Indonesia is conducted by stipulating several regulations, firstly, Child Protection Act No. 23 of 2002 and the Law on Eradication of Human Trafficking Crime Number 21 of 2007, besides Indonesia has ratified the UN Convention on Human Rights Rights of the Child (CRC) through Presidential Decree No. 36 of 1990. Efforts made to prevent and control the CSEC in Medan City, namely: to socialize in cooperation with various agencies to conduct prevention and prevention of criminal act in the city of Medan CSEC; building networks with various non-governmental organizations and with various institutions to give birth to Regional Regulation (Perda) Number 6 of 2004 on the Elimination of Trafficking in North Sumatra, making efforts of legal advocacy and advocacy from the Prosecutor to the Court; provide assistance to rehabilitate the physical and psychological child victims of CSEC (counseling and medical) and provide safe homes for children. Obstacles in preventing and preventing CSEC in Medan are: legislation that has not been specifically set CSEC, social, economic and psychological factors such as the attitude of community permissive or ignorance of CSEC issues, closed or complicated bureaucracy.
\end{abstract}

Keywords: Efforts, Countermeasures, CSEC

\section{INTRODUCTION}

The conception of child protection from various forms of crime such as the Child Sexual Exploitation (hereinafter referred to as CSEC) has been confirmed in various legal provisions, at the level of international law the recognition of the existence of children as subjects of human rights has been realized by ratifying the Convention on the Rights of the Child by 193 countries, thus as many as 193 governments including the Indonesian government have accepted their obligation to take all measures to protect children from forms of violence and exploitation.

Ratification of the Child Right Convention (CRC) does not automatically provide for the full protection of violence, exploitation, and abuse of power of children and even its implementation is still very weak. Children as an integral part of the community's most vulnerable ability to protect themselves, often the object of all forms of crime, violence and exploitation and forms of crime against children in various forms that degrade the child's dignity are plural and widespread in communities such as schools, at home, and the environment around the child's home.

The state of the economy of a country, the level of poverty and unemployment and the increasingly limited access to prosperity and modern lifestyles that all consumptive make some people make various efforts to survive to meet the economic needs of themselves and their families. The situation is one of the reasons to ignore all the ways with the pretext of looking for a bite of rice, one of which is by way of ESKA, but not poverty alone is one factor of the emergence of sexual crimes, poverty will be a very severe if access to education, health, or social development programs, for example, are not owned by a group that is in dire need, it shows the relative access structure problem and very decisive for the welfare of society. 
The term ESKA has not been widely heard or is not well understood, although actual cases related to sexual crimes have been widely found either through print or electronic media, in 1998 according to a survey conducted by Unicef recorded about 40,000-70,000 children became victims of crime Sexually every year, although many other sources say that number is still far from reality, the majority of them are forced to work in the sexual trafficking, according to Sulistyaningsih and hull in Eka, there are about 40,000-70,000 children out of total prostitutes in Indonesia which is about 140,000 -230,000 people, but if referring to data released by the National Coalition on Commercial Sexual Exploitation of children the figure is more than that stated (Rehulina, 2008).

The development of the sex industry in some countries, including Indonesia has boosted market demand for children for sexual needs, resulting in more and more children being forced into commercial sex workers (CSWs). The majority of them are forced to work in the sex trade. The practice mainly takes place in prostitution centers, entertainment venues, karaoke, massage parlors, shopping centers, and others.

CSEC in international law even though it has a firm conception of rules, but it needs to be seen and guaranteed its implementation in each participating country including Indonesia, so that the rules About CSEC is not only a child protection display. The child as an element that needs comprehensive protection awaits thorough steps to protect from CSEC and other crimes.

Children's problems including CSEC are a lot of research and research needed to find solutions to solve them. Based on the background descriptions previously described it is deemed necessary to raise the research by title. The biggest problem that is often studied in criminology and criminal law studies in criminal cases is the motive, and the reason of the perpetrator of the crime committed a crime. In the context of this research to be discussed and become the boundary or scope of the problem is about the provisions of the law that regulate the sexual exploitation of children, the factors that become the perpetrator's motive, and whether there is a motive derived from the understanding of consumerism from the self-perpetrators who examined from cases handled by law enforcement.

\section{LITERATURE REVIEW}

\subsection{Understanding and Age Limitation Children}

The definition of a child nationally is based on the age limit of the child according to criminal law, civil law, customary law and Islamic law, internationally defined in the United Nations Convention on the Right of The Child of 1989, minimum standards of the United Nations on Implementation Juvenile Justice (The Beijing Rules), 1985 and the Universal Declaration of Human Rights of 1948, nationally the definition of the child according to the Laws, including explaining the child is a person who have not reached the age of 21 years or not married (Marlina, 2009).

Positive law in Indonesia has a pluralism of understanding and regulation About the child, for example in Article 330 of the Civil Code (Civil Code) determines that a child is a person who has not reached the age of 21 (twentyfirst) Year and not first married, -Undonesia Number 23 Year 2002 regulating the child is a person who is not yet 18 (eighteen) years of age, including a child who is in the womb.

Understanding the child according to Wiryono Prodjodikoro in Maidin is called an immature (minderjaring / person under age), minors (minerjarigheid / inferiority) or often also referred to as a child under the supervision of the guardian (minderjarige ondervoordij), customary law determines a person is said to be immature not of age, but the size used is to be self-employed, able to do something, whereas in Islamic law, the adult limit is determined if men are already baligh and women have experienced menstruation, starting from that aspect turned out positive law of Indonesia has not yet established universal and universally applicable legal unification to determine ageconstraining criteria for a child (Gultom, 2008).

Law No. 23 of 2002 on the protection of the child, in Article 1 paragraph (1) point (a), the child defines the following: a child is not yet 18 (eighteen) years of age, including a child in the womb, positive Indonesia, the age limit for a child the criteria vary, there is a positive law of Indonesia that determines the age limit of a child with a maximum age limit of 18 years, under 17 years, under 21 years of age, under 16 years and under 15 years, therefore, with the birth of Law No.23 of 2002 on child protection, it becomes clear that what is the definition of the child, the child is a party protected by the State through national law has several rights and obligations, based on Law No. 23 of 2002 About Child Protection.

\subsection{Legal Protection for Children}

Legal protection for children in the level of international law can be interpreted as a legal protection against various fundamental rights and freedoms of children and various interests related to the welfare of children, so the issue of legal protection for children covers a very wide scope.

Departing from the above limitations, the scope of legal protection for children includes:

1) Protection of child freedom 
2) Protection of the rights of children, and

3) Legal protection of all welfare-related interests of the child.

The state perspective regulates the state's commitment to protect its citizens, including those of the child, can be found in the opening of the 1945 Constitution, the State's juridical commitment to protect its citizens as mentioned in the fourth paragraph of the 1945 Constitution, further elaborated CHAPTER XA on the Rights Human Rights (HAM), specifically for the protection of children, Article 28B paragraph 2 of the 1945 Constitution states that every child has the right to survival, development and development and is entitled to protection from violence and discrimination (Waluyadi, 2009).

Child protection is endeavored by every person, parents, family, community, government and country, pursuant to Article 20 of Law No. 23 of 2002 on Child Protection (hereinafter referred to as the LoGA) determines the state, government, community, family and parents shall be responsible and responsible for the organization of child protection, so those who seek child protection are every member of the community according to their ability with various businesses in certain situations and conditions, every citizen takes responsibility for the implementation of child protection for the welfare of the child.

Child happiness is a shared happiness, a protected happiness is a sheltering happiness, no unrest in children because child protection is well done, and children become prosperous. Child welfare has a positive influence on parents, family, community, Government and State, Coordination of child protection activities cooperation needs to be done in order to prevent imbalance of child protection activities as a whole, obligation and responsibility of State and Government in child protection effort regulated in Law Number 23 of 2002 which are:

1) Respect and guarantee the human rights of every child regardless of ethnicity, religion, race, class, sex, ethnicity, culture and language, legal status of children, birth order and physical or mental condition (Article 21)

2) Providing support facilities and infrastructure in the implementation of child protection (Article 22)

3) Ensure the protection, care and welfare of the child with due regard to the rights and obligations of parents, guardians or other persons who are generally responsible for the child and oversee the implementation of child protection (Article 23)

4) Ensure the child to exercise his right to express opinions according to the age and level of child intelligence (Article 24).

\section{METHODOLOGY}

\subsection{Aproach Research And Data}

This type of research includes sociological juridical legal research with case study approach. Case studies were used to examine cases of sexual exploitation of children through the analysis of court decisions handed down to defendants, while exploratory analyzes were conducted to find the root causes of criminal offenses in order to find the mitigation measures. The focus of this research is the case of sexual exploitation of children who was decided by the Medan District Court with the object of a court decision that has a permanent legal force (inkracht van gewisjde). This step is directed to experts, judges, prosecutors, police and legal counsel taken in a random system. Various literatures were studied in relation to the study of child sexual exploitation and criminology studies, books, journals, court decisions, writings in the mass media, all related to the research focus of the researcher and used for descriptive descriptive data obtained from the exploratory study. Data to be discussed around child sexual exploitation crime consisting of legal experts and practice. Data analysis techniques conducted qualitatively. The reason for choosing qualitative techniques is because the analysis can produce descriptive data. Qualitative analysis is used to obtain the meaning of the relationship between variables or to analyze the dynamics of relationships between phenomena by using scientific logic. Qualitative research attempts to answer research questions through formal and argumentative ways of thinking (Azwar, 2003: 5). Qualitative analysis in this study was conducted to find the root description of radicalism on terrorist acts in cases of sexual exploitation of children who have been terminated (incracht).

\section{RESULT AND DISCUSSION}

\subsection{Arrangement Against CSEC in Indonesia}

The regulation of CSEC in Indonesia has existed in various laws, such as the Child Protection Act, the Law on the Eradication of Criminal Acts and its implementing rules as a form of fundamental safeguard through the application of law to the interests of the child. In the protection of children against threats of CSEC crimes, the law always has the objective of two (2) directions of punishment if there is action against justice and harassment if such action has not occurred. This is applied to all subject / legal object either state, corporation, or individual. Thus, the state is an entity that is not immune from the law.

Every wrongdoing (based on criminal law) either because negligence (culpa) or deliberate (dolus) obliges the state to take an accountability action. The reflection of the state's responsibilities can then be of any kind depending on 
what mistakes are made. In relation to Human Rights, the state has always been placed as a protective entity against its citizens as its most essential duty. (Irwanto, 2008)

The State has transferred its responsibilities into a Basic Constitution of the State. 1945 Constitution of the State of the Republic of Indonesia Article 28 I (4) states that "The protection, promotion, enforcement and fulfillment of Human Rights is the responsibility of the state, especially the government".

Speaking of Human Rights, there should be four main principles underlying every international convention on human rights, including the Convention on the Rights of the Child (CRC), that is, human rights apply to all persons without exception (universality and inalienability), human rights are mutual dependent and inseparable (interdependence and indivisibility), and these principles contain the rights and obligations (the principle of human rights as entailing rights and obligations).

These principles are based on universal values of freedom, independence, equality and non-discrimination and justice. In connection with this issue, there are several things to note whether the issue of children get attention attention or interests higher than adults in the protection of human rights. (Irwanto, 2008).

At the level of international law protecting the child's interests against the CSEC Crime there is the Council of Europe's Council on the Protection of Children from Sexual Exploitation and Sexual Violence to acknowledge the link between sexual violence against children and sexual exploitation of children and includes so many violations such as involvement in sexual activities with a child who has not reached the age of sexual consent, child prostitution, child pornography and causes a child to witness sexual violence or sexual activity.

The Convention also addresses the issue of violence and exploitation of children in a very holistic or holistic manner requiring preventive, protective and protective measures or the protection to be taken and the treatment of victims. There is an Explanatory Report for the Council of Europe Convention which is very useful for interpreting its aims and assisting States to implement these goals at the national level.

According to the Convention, States are explicitly permitted to exercise their right to criminalize certain acts which limit their uniformity of application throughout the States that have ratified the Convention. The table below lists examples of violations that the State should consider for inclusion in their Criminal legislation. (Ahmad Sofian, 2012).

The CRC regulates the rights of the child but leaves it to the State to decide who is meant by a child. More precisely, the CRC defines a child as any person under the age of 18 but at the same time allows the State to determine an adult age early. In general, adults are understood as a legal concept that defines uasia in which a person becomes a truly mature person.

According to the CRC, a child is defined as any person under the age of 18, except under applicable law for a child it is determined that an adult age is reached earlier. In practical terms, a person has reached adulthood can be capable of doing things such as marrying without permission from others and voting or performing a legally binding contract. National laws provide different adult age and there are many differences within the jurisdiction and between jurisdictions.

When a State determines low adulthood for example 14, one of the immediate effects is that people between the ages of 14 and 18 can get out of the scope of CRC protection because they will not perceive as 'children' anymore within their national jurisdiction. The issue has been raised by the Committee on the Rights of the Child which has repeatedly stated that the provisions of the CRC must benefit all children up to the age of 18 years as dilustrasika by the example below.

Indonesia has issued legal provisions in the field of child protection especially in the prevention and prevention of CSEC, firstly, Indonesia has ratified the United Nations Convention on the Rights of the Child (CRC) through Presidential Decree Number 36 of 1990 which became an important momentum in the efforts of the government and society in protecting the rights of the child.

This Convention is a treaty or international treaty governing the recognition, respect and protection of the fundamental rights of the child. In Article 32 all States parties are expected to protect the child from all forms of exploitation that endanger the physical and moral of the child. Article 34 specifically expects all States Parties to take action at the national, bilateral or multilateral level to prevent the exploitation of children for sexual purposes.

The Convention on the Rights of the Child (CRC) has existed since 1990 but the umbrella of child protection law in Indonesia has only been realized through the birth of Law no. 23 of 2002 on Child Protection. In this law it is stated 
that the perpetrators of CSEC are threatened with 15 years in jail or fined at most 100 million. Several other laws relating to CSEC include: Law no. 39 of 1999 on Human Rights, Law No.23 of 2004 on Domestic Violence (KDRT), Law no. 21 Year 2007 on the Elimination of the Crime of Trafficking in Persons, Law No.11 Year 2008 on Information and Electronic Transactions, Law no. 1 of 2000 on the Reflection of ILO Convention 182, PP. 9 of 2008 on the Procedures and Mechanism of Services for Witnesses and / or Victims of Trafficking in Persons. In addition, in 2005 after formulated a comprehensive policy that includes the issue of children as one of the main issues in national development. This policy document is called National Development for Indonesian Children 2005. Indonesia has also signed international instruments but has not yet ratified them:

1) Organized Transnational Crime Conventions and their protocols are: protocols to prevent, suppress and punish traffickers, especially children and women.

2) Optional Protocol to the Convention on the Rights of the Child on the Sale of Children, Child Prostitution and Child Pornography.

Indonesia has ratified the United Nations Convention on the Rights of the Child (CRC) through Presidential Decree no. 36 of 1990 which became an important momentum in the efforts of government and civil society in protecting children's rights. This Convention is a treaty or international treaty governing the recognition, respect and protection of the fundamental rights of the child. In article 32 all forms of exploitation which endanger the physical and moral of the child. Article 34 specifically expects all States Parties to take action at the national, bilateral or multilateral level to prevent the exploitation of children for sexual purposes, including child pornography.

The issue of sexual exploitation of children has received a global response embodied in the World Congress to eliminate commercial sexual exploitation of children in Stockholm. Sweden in 1996. This meeting resulted in the Stockholm Agenda which contained various actions to be taken by participating countries, including Indonesia. As a result of the global movement to abolish sexual exploitation of children, in 2000 the United Nations drafted an optional protocol specifically to address child trafficking, pornography and child prostitution (Optimal Protocol on the sale of children, child prostitution and child pornography) 2002.

Indonesia has signed this optional protocol and according to the 2004-2009 RAN HAM should have been ratified in 2005 but has not been implemented until now. Nevertheless, please note that Indonesia's commitment has been realized by building a national coalition and creating a National Action Plan (RAN) passed through Presidential Decree no. 87 of 2002 which was followed by the formulation of child and women trafficking RAN through Presidential Decree no. 88 of 2002.

Legislatively, Indonesia has shown significant progress in demonstrating its commitment to eradicating child sexual exploitation and trafficking. This is realized with the issuance of Child Protection Law no. Law No. 23 Year 2002 and the Law on Eradication of Human Trafficking Criminal Act. 21 Year 2007. In addition, in 2005 has formulated a comprehensive policy that includes the issue of children as one of the main issues in national development.

This policy document is called the National Development for Indonesian Children (PNBAI) 2015. This document outlines medium-term development plans to improve the quality of health, education, HIV / AIDS prevention and child protection-such as the need for legal development and legal mechanisms to protect children of various forms exploitation, facilities and infrastructure services to assist victims.

The ESKA regulation is not specific to Article 82 of Law Number 23 Year 2002 regarding Child Protection which reads:

"Anyone who deliberately perpetrates violence or threats of force, forces, tricks, a series of lies or persuades a child to commit or permit an obscene act with a maximum imprisonment of 15 (fifteen) years at the latest 3 (three) years and a fine of at most Rp.300.000.000 (three hundred million rupiah) and at least Rp.60.000.000 (sixty million rupiah)."

The provision of Article 82 becomes the legal basis to ensnare the perpetrators of the crime of CSEC, the criminal acts categorized as ESKA in the Article are incorporated into the definition of lewd acts. This provision becomes the legal basis to ensnare the perpetrators of ESKA that is any action that is categorized as obscenity either with kekrasan or coercion or through subtle way although still not specific regulate ESKA.

The Child Protection Act also provides for restrictions on the conduct of CSEC in emergency situations such as riots, armed conflicts or natural disasters in Article 78 with a maximum penalty of 5 (five) years and a maximum fine of $\mathrm{Rp} \mathrm{100,000,000} \mathrm{(one} \mathrm{hundred} \mathrm{million} \mathrm{rupiah)} \mathrm{in} \mathrm{addition} \mathrm{to} \mathrm{the} \mathrm{provision} \mathrm{of} \mathrm{Child} \mathrm{Sexual} \mathrm{Violence} \mathrm{(KSA)} \mathrm{in}$ Article 80 with a minimum penalty of 3 years 6 months up to 10 years and a fine of at least Rp.72.000.000 (seventy two million rupiah) and a maximum of Rp.200,000. 000 (two hundred million rupiah). 
The legal basis also governs sold / trafficked children or child trafficking for the benefit of prostitution (sexual). This is contained in Article 2 paragraph (1) of Law Nomo 21 Year 2007 on the Eradication of Child Trafficking Crime which reads:

"Any person hiring, transporting, sheltering, shipping, transferring, or receiving a person with threats of violence, abduction, capture, forgery, fraud, abuse of power or vulnerable positions, debt bondage or pay or benefits despite obtaining the consent of the person holding control of another person for the purpose of exploiting that person in the territory of the Republic of Indonesia shall be liable to a maximum imprisonment of 3 (three) years and a maximum of 15 (fifteen) years and a fine of at least Rp.120.000.000,00 (one hundred and two tens of millions of rupiah) and at most Rp.600,000,000.00 (six hundred million rupiah). "

In 2002 the government issued a Presidential Decree closely related to the ESKA, namely Presidential Decree No. 87 of 2002 on National Action Plan (RAN) ESKA and Presidential Decree No. 88/2002 on the NAP on the Elimination of Trafficking of Women and Children. This decree was followed by the birth of local regulations in a number of regions. Particularly in North Sumatra has been issued Perda No. 6 of 2004 on Trafficking in Persons.CSEC has become one of the priority issues of Indonesian government legal provisions that have been submitted before then re-realized in the lower regulation through the Regulation of the Coordinating Minister for People's Welfare No. 25 / KEP / MENKO / KESRA / IX / 2009 on the National Action Plan for the Eradication of Criminal Act of Commerce People and Sexual Exploitation of Children, which furthermore becomes the national reference in the prevention and prevention of child trafficking and child exploitation.

\subsection{Prevention And Crime Prevention Of CSEC In Medan City ESKA Practice And Its Cause Factors in Medan City and Surroundings}

CSEC is a very worrying phenomenon of its development, especially in Medan and in some areas in North Sumatra. The expanding sex industry in some areas has boosted market demand for children. So more and more children are forced into Commercial Sex Workers (CSWs). Ahmad Sofyan quoted Kompas's note on this phenomenon that in Indonesia, 40,000-70,000 children have been victims of CSEC. The majority of them are forced to work in the sex trade. The practice mainly takes place in prostitution centers, entertainment venues, karaoke, massage parlors, shopping centers, and others. However, the perpetrators are local residents. More details according to Social Services data, in Semarang, Yogyakarta and Surabaya, there are 3,408 children victims of prostitution both in localization, street, places of entertainment, and massage parlors. In West Java the number of children prostituted in 2003 was 9000 children or about 30 percent of the total PSK 22,380 people (Erwin, 2011).

This amount certainly does not include Indonesian children who become victims of prostitution abroad. For child pornography is equally alarming. Not a few Indonesian children who became the object of pornography. Both in video and photo formats. As happened in 2006. Peter W Smith, an Australian citizen claimed to have kidnapped 50 Indonesian children and recorded it in movie and photo format. (Erwin, 2011).

This amount certainly does not include Indonesian children who become victims of prostitution abroad. For child pornography is equally alarming. Not a few Indonesian children who became the object of pornography. Both in video and photo formats. As happened in 2006. Peter W Smith, an Australian citizen claimed to have kidnapped 50 Indonesian children and recorded it in movie and photo format. (Erwin, 2011).

The problem of CSEC as part of the child's problem is a problem that has not been resolved until today. The Government considers this problem is a small problem that is not so disturbing the stability and political atmosphere in Indonesia this we see from the steps taken to take steps to anticipate and countermeasures. There is no thought of the government to arrange a program to alleviate this problem.

The government is still too busy solving conflicts between interests that are playing. Unfortunately the children continue to be sent to prostitution fields whether it is cloaked localization, hotels, karaoke and so on. It means victim after victim continues to fall, while the response to this problem is still little to give it. In the issue of prostituted children, there are many parties involved and receive huge profits for this illegal business. But for children, this is very detrimental, especially for the future.

Children are made more prostitutes due to increasing market demand. The high demand for children especially those aged 14-17 years because they are considered 'holy' from various viruses and diseases. A pimp who managed to provide a virgin young girl then he can reap millions of dollars in profit for one transaction with a customer. For these reasons, pimps make every effort to get 'young grass'.

There is no valid data to determine how many Indonesian children are victims of CSEC even though some cases have been revealed. At this time, based on the various reports available, child trafficking has taken place in various regions with larger areas of origin and destination. The problem is increasingly complex considering that a particular 
region is not only a destination but also a region of origin and transit area. The fantastic amounts presented above suggest that CSEC should not be regarded as a trivial matter of children.

Medan city is one of the most vulnerable cities of ESKA in Indonesia. The phenomenon of children who became victims of sexual in this city is quite memorable for a long time, even already recorded the practice has been running since the 1970s. In the era of the 70s stood the term "gongli", "perek", "girl basin" and others. In 1998, the phenomenon of children began to bloom in Medan. Child prostitutes in the city of Medan can be divided into two types based on the compensation they receive from the "consumer", namely: first what is called "Bonsay" and second is "rent" (Rehulina, 2008).

Identification of Medan City as one of the big cities that are vulnerable to ESKA can be known from survey conducted by PKPA Medan related to ESKA phenomenon in Medan City. In mapping the situation and problems of ESKA in Medan and surrounding areas PKPA Medan has conducted a survey. The focus of the survey is the issue of child prostitution and trafficking for the purpose of prostitution, it is difficult to find children victims of pornography. Children as parties involved in prostitution interviewed in this survey there are two categories, categories with the status of students and not the status of students.

The survey took place from September 2016 to June 2017 survey sites in North Sumatera by sampling in 5 districts / cities of Medan, Tanjung Balai, Serdang Bedagai, Langkat and Nias districts. Respondents in this survey were child victims of prostitution and sexual exploitation for commercial purposes.

Parties involved in the practice of child trafficking are: Salon owner, cafe owner, discotheque / karaoke businessman, hotelier, consumer (child sex campaigner), school friend, girlfriend. In the case of child prostitution, the practice of sexual exploitation of children with the status of students takes place in star hotels in Medan. After school children who have been booked will be taken to hotel for check in. Start hotel security until the hotel manager knows exactly that the guest is carrying a woman who is not yet 18 years old and still a student, but they close their eyes on the issue and let the practice of sexual exploitation take place. Some cases have children who have sex with a girlfriend / raped. Next the friend who first plunge into this world then invites him to participate in the practice of prostitution.

In the case of child trafficking, the involved parties are the owners of cafes or salons, making their salon or cafe into a place of sexual exploitation of children. Salon or cafe provides a special room / place for sexual intercourse. Guests who come can choose a child who works in the place. The salon or cafe is just a cover for practicing sexual exploitation.

The practice of child prostitution spreads from friend to friend. A senior friend, introducing the "potentially" to the guest or tubang. This old player will then get more tips from tubang or guests. Sometimes there are guests / tubes looking for virgins. For a virgin child who will be deployed in the practice of sexual exploitation will be rewarded 38 million rupiah, while the carrier will get a new mobile unit and a sheet of rupiah between 100-500 thousand.

Child trafficking cases spread through underage migrant workers promised jobs as Domestic Helper (PRT) / other types of work, but were found to be employed in lokalisasi. Especially for salon workers, then everyone who brings other salon / cafe workers will get special tips from salon owners and salary increases.Consumerism, courtship crossing the line and losing a virgin and feeling himself no longer worthy, dominate as a very powerful factor in herding the child victim to CSEC. Confusion over economic issues and economic identity and social identity, lack of family attention, confide and misinformation also encourage children to make unwise decisions and must sell their honor in order to earn money.

\subsection{Prevention And Response Of CSEC}

CSEC as part of an ever-increasing crime each year requires efforts to be prevented and mitigated so that this practice can be suppressed. Efforts to prevent and mitigate CSEC are then manifested in concrete actions by making the following efforts: (1) through the penal path (criminal law) which focuses more on the repressive nature; and (2) through nonpenal channels, focusing more on preventive or preventive attributes before the CSEC crime occurs.

The overcoming of CSEC through nonpenal pathway is also conducted with the main objective of addressing the factors conducive to the occurrence of CSEC crime, which is centered on social conditions that directly or indirectly can foster crime. Efforts to prevent CSEC are also called non-penal efforts that are more directed at prevention of criminal actions of CSEC which are more preventive (preventing) before the criminal act of CSEC is happened. 
Non-penalty efforts are made by not using legal instruments, especially criminal law, but more persuasive measures. While penal effort is done by using criminal law as a tool to overcome ESKA and do various repressive efforts, that is problem solving step after practice of CSEC and assistance effort to rehabilitate child victim of this practice.

Much effort has been made to protect children and prevent them from commercial sexual exploitation. The effort should be done at the strategic level, ie at the global, national and local level by involving many parties, including government, law enforcement, non-governmental organizations, the private sector to the bottom line, especially at the smallest level of family, this has a great influence in preventing the occurrence of CSEC practices.

One of the non-governmental organizations (NGOs) that are conserned in preventing and handling ESKA in Medan City is the Center for Child Protection and Study (PKPA) Medan. PKPA was established against the background of the need for child protection in the era of globalization that threatens children.

The process of social change and industrialization that occurred in Indonesia resulted in the erosion of humanitarian value, resulting in the erosion of creative power and intelligence of children, because humans and especially children are limited space and role. This is what prompted the establishment of this institution on 21 October 1996, to anticipate the issue actively. The purpose of this institution is to provide protection and legal assistance, especially to children, to study the various problems faced by children to find a solution, and to educate children by supplying reading material.Fields and forms of activities: The main areas of activity of this institution are children, health, which are also supported by law, human rights and population. Fields of activity of this institution are carried out in the form of activities: study and research, education and training. It is also supported by community development and advocacy, advocacy and publication.

Programs that have been conducted include socialization of HIV / AIDS against street children in Medan, street children research, and research on jermal child labor. Publication by publishing Book of Child Protection Legal Aspect and Info Sheet Bulletin. Sources of funding comes from Government funding sources derived from government subsidies, assistance from various international institutions, such as The Toyota Foundation, Ford Foundation, and revenue from cooperation projects with other parties. Membership and area of work: In the regional sphere it becomes a member of the WIM (Information Society) and the Indonesian Child Labor Network (JPPAI). While the working area covers Medan.

Efforts to prevent and overcome the CSEC that has been and will be run by PKPA implemented by involving various parties by doing the following steps:

a. Continuous community awareness campaign;

b. Development of alternative income sources for families prone to CSEC;

c. Mainstreaming children's rights and strengthening the legal system for the prevention of CSEC PKPA Medan assistance and advocacy program as an effort

Prevention efforts are conducted through cooperation with various agencies to prevent and control criminal act of ESKA in Medan City, this socialization effort is done by dissemination of regulation and development related to child protection from CSEC through several ways, namely: First, internet path by opening website pages (www.pkpa-indonesia.org, www.ecpat.net) while also opening other services through facebook, email, and contact channels via telephone communication. Second, socialization is also conducted through extension activities to prevent CSEC to schools, Third, establish KOMPAK (Community of Anti Trafficking in Persons and CSEC), children who are members of this container are trained and given knowledge about CSEC and the handling is then given skill and the obligation to deliver it to other schools throughout Medan City. Fourth, holding a Talk Show and discussions on government radio, and Fifth, anti-CSEC campaigns conducted at Siantar, Tebing and Medan were carried out in 2010.

\section{CONCLUSION}

Law enforcers Child exploitation on the protection of children's rights is contained in the 1989 Convention on the Rights of the Civil (1989) Convention, ratified by more than 191 countries, including Indonesia as a member of the UN through Presidential Decree No. 36 of 1990 , thus, the UN convention has become law, in 1999, Indonesia passed Law No. 39 of 1999 on Human Rights which in it also regulates the rights of children through several Articles, then, three years later, Law Number 23 Year 2002 on Child Protection (BAL).

Implementation of International Law in Child Protection from CSEC in Indonesia is done through the legislation that is by ratifying the international rule of child protection field, in the field of legislation is realized with the birth of Law Number 23 Year 2002 About Child Protection. The explanation of UUPA affirms that the accountability of parents, family, community, government and state is a continuous series of activities for the protection of children's rights. Efforts to protect children from ESKA need to be implemented as early as possible from the womb until the 
age of 18 , executives by strengthening the role of law enforcement officers such as the police, and education as a preventive path.

\section{REFERENCE}

Ahmad Sofian, 2012. Perlindungan Anak di Indonesia, Dilema dan Solusinya. Jakarta, PT. Sofmedia. Bambang Sunggono.2012. Metodeologi Penelitian Hukum. Jakarta: Raja Grafindo Persada.

Eka Dalanta Rehulina. 2008. Eksploitasi Seksual Komersial Anak di Indonesia. Medan: Koalisi Nasional PESKA. Iwayan Parthiana 2002. Hukum Perjanjian Internasional Bagian 1.Bandung. Mandar Maju.

Irwanto, 2008. Menentang Pornografi dan Eksploitasi Seksual terhadap Anak. Medan, Koalisi Nasional Penghapusan Eksploitasi Seksual Komersial Anak.

Marlina, 2009, Peradilan Anak Pidana di Indonesia, Bandung, Refika Aditama

M.Marwan. 2009. Kamus Hukum. Surabaya. Reality Publisher.

Maidin Gultom 2008, Perlindungan Hukum Terhadap Anak, Bandung, Refika Aditama.

Ramlan. 2010. Memperkuat Hukum Penaganan Eksploitasi Seksual Anak, Sumatera Utara Indonesia: ECPT Internasional.

, 2006. Melindungi Anak-Anak dari Eksploitasi Seksual Dalam Situasi Bencana dan Gawat Darurat. Medan : ECPAT Internasional.

Rika Saraswati 2009, Hukum Perlindungan Anak di Indonesia, Bandung, Citra Aditya Bakti.

Waluyadi, 2009, Hukum Perlindungan Anak, Refika Aditama, Bandung, Mandar Maju.

Undang-Undang Nomor 23 Tahun 2002 Tentang Perlindungan Anak.

Kitab Undang-Undang Hukum Pidana.

Konvensi Hak-Hak Anak Tahun 1989

Protokol Opsional Konvensi Hak Anak Tentang Keterlibatan Anak Dalam Konflik Bersenjata.

Arti kata Penanggulangan, Melalui http//www.artikata.com diakses tanggal 31 desember 2012. 